\title{
ОПИСАНИЕ ПРОТИВОВИРУСНЫХ СВОЙСТВ АНАЛОГОВ ЦИТИЗИНА ПРОТИВ КОРОНАВИРУСА ОС43
}

\section{Я.Л. Есаулкова', А.А. Мурылёва', А.В. Ковальская², И.П. Цыпышева², B.B. Зарубаев'}

${ }^{1}$ Лаборатория экспериментальной вирусологии, Санкт-НИИ эпидемиологии и микробиологии им. Пастера, 197101, Россия, Санкт-Петербург, ул. Мира, д. 14.

2Лаборатория биоорганической химии и катализа, Уфимский Институт химии УФИЦ РАН,450054, Россия, г. Уфа, проспект Октября, д. 71

DOI: 10.19163/MedChemRussia2021-2021-458

E-mail: lanaEsaulkova@gmail.com

В последние годы возникла острая необходимость в создании терапии против вирусов семейства Coronaviridae. Мы протестировали на наличие противовирусной активности аналоги цитизина, так как в этой группе были выявлены соединения с противовирусной активностью широкого спектра. Целью работы была идентификация соединений, проявляющих ингибирующую активность в отношении коронавируса ОС43. Использовали соединения, синтезированные в Уфимском научном центре РАН. Активность оценивали в культуре клеток аденокарциномы легких человека Н-23 против коронавируса ОС43.
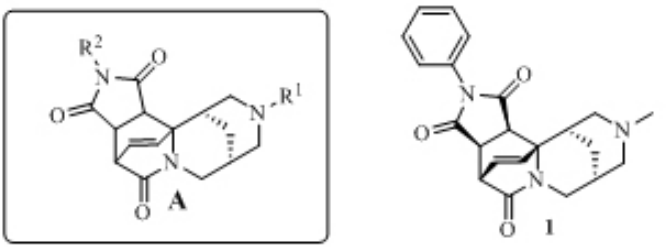

Pис. 1. Библиотека производных цитизина А и соединение-хит 1

Для оценки противовирусных свойств соединений использовали метилтетразолиевый тест и реакцию гемагглютинации. С их помощью определяли 50\% цитотоксическую концентрацию (СС $\left.{ }_{50}\right)$ - концентрацию соединения, при которой 50\% клеток погибают, и 50\% ингибирующую концентрацию, при которой активность вируса снижается на $50 \%\left(\mathrm{IC}_{50}\right)$. На их основе вычисляли индекс селективности (SI) - отношение $\mathrm{CC}_{50} / \mathrm{IC}_{50}$. Соединения, чей SI превышал 10, считали перспективными для дальнейшей разработки.

По результатам работы было отобрано пять перспективных соединений, четыре из которых не проявляли токсических свойств в диапазоне концентраций до 245 мкг/мл. При этом все пять соединений проявили активность против коронавируса OC43 в концентрации не более 20 мкг/мл. Наибольшей противовирусной активностью обладал (3aR,4S,8S,12R,12aS,12bR)-10-метил-2-фенил3а,7,8,9,10,11,12,12 b-октагидро-1Н-4,12а-этено-8,12-метанопирроло[3',4':3,4] пиридо[1,2-а][1,5]диазоцин-1,3,5(2H,4H)-трион 1 (Рис. 1, $C_{50}=273, \mathrm{IC}_{50}=7, \mathrm{SI}=39$ ). Таким образом, аналоги цитизина являются перспективными для разработки прототипов препаратов против коронавирусной инфекции. 